\title{
Genetic improvement of fibre traits in perennial ryegrass
}

\author{
M.J. FAVILLE ${ }^{1}$, K. RICHARDSON ${ }^{1}$, M. GAGIC ${ }^{1}$, W. MACE ${ }^{1}$, X.Z SUN ${ }^{1}$, S. HARRISON ${ }^{1}$, K. KNAPP ${ }^{1}$, \\ M.Z.Z. JAHUFER ${ }^{1}$, R. PALANISAMY ${ }^{1}$, S. PIRLO ${ }^{1,2}$, R. JOHNSON ${ }^{1}$, S. RASMUSSEN ${ }^{1}$ and G. BRYAN ${ }^{1}$ \\ ${ }^{1}$ AgResearch Ltd., Grasslands Research Centre, Private Bag 11008, Palmerston North 4474 \\ ${ }^{2}$ Current address: DPI Victoria, Hamilton, Victoria, Australia \\ marty.faville@agresearch.co.nz
}

\begin{abstract}
Genetic changes in fibre characteristics of perennial ryegrass (Lolium perenne) may enhance degradability and thereby improve voluntary feed intake and energy availability from ingested grass. Plant breeding and genetic modification (GM) approaches to altering fibre composition have been initiated, with the ultimate objective of developing cultivars with improved fibre degradability. Ryegrass was modified with gene constructs designed to reduce the activity of key genes in lignin biosynthesis, a major component of fibre that impedes digestion. Concurrently, a grass fungal endophyte was manipulated to express enzymes that digest the structural components of grass fibre. Development of new analytical tools have enabled mining of a diverse collection of ryegrass germplasm, and natural variants were identified for both lignin concentration and levels of specific cell wall compounds that were shown to correlate with forage digestion rate. Both conventional breeding and GM strategies may be exploited to improve degradability traits in perennial ryegrass but further development will be required.
\end{abstract}

Keywords: degradation kinetics, digestibility, diferulic acid, hydroxycinnamic acids, lignin

\section{Introduction}

Perennial ryegrass (Lolium perenne) is an important source of nutrition for ruminant livestock on most New Zealand farms. However, it is commonly recognised that grazed pasture does not provide sufficient nutrition to meet the genetic potential for production of ruminants. One reason for this shortfall relates to the inaccessibility of fibre in the forage to microbial degradation in the rumen (Kristensen et al. 2005).

Fibre is the structural component of plants and is a source of energy for grazing animals as cell wall polysaccharides (hemicelluloses and celluloses). The nutritional availability of this energy is limited by the extent to which fibre can be digested by rumen microbes. In addition to total digestibility, the degradation rate of fibre in the rumen limits passage through the gastrointestinal tract (Baumont et al. 2000), constraining voluntary feed intake, a critical determinant of animal performance (Allen 1996).

Increasing the rate and extent of degradation of the fibre may enhance energy availability and potential intake of forage cultivars (Jung \& Allen 1995). To this end, fibre chemical composition in forage grasses have also been targeted for alteration by plant breeding (Casler \& Jung 1999; Casler et al. 2008) and genetic modification (GM) (Chen et al. 2003; Buanafina et al. 2010).

The fibre components of most interest include lignin and hydroxycinnamic acids (HCA's). Lignin is a constituent of plant cell walls that binds polysaccharides to form a dense matrix, creating a physical barrier to microbial enzymes and limiting degradation of cell wall polysaccharides (Jung \& Deetz 1993). HCA's, notably ferulic acids, form cross-links between polysaccharide chains in the cell wall and between hemicellulosic polysaccharides and lignin (Hatfield et al. 1999), further obstructing cell wall degradation (Grabber et al. 2004). Heritability estimates for concentration of lignin and ferulates (Casler et al. 2008) are sufficiently high to warrant breeding for these traits in forage grasses.

Three initiatives are described, including both conventional breeding and GM approaches, which aim to develop perennial ryegrass cultivars with altered fibre composition and enhanced degradability.

\section{Breeding for improved fibre composition Tools for quantifying HCA's}

Selection of plants with naturally low concentrations of cell wall HCA's for breeding (Casler \& Jung 1999; Casler et al. 2008) may improve forage degradability in grasses. Most notably, dimeric forms of the HCA ferulic acid (diferulic acids, DiFA's) correlate negatively with the extent (Lam et al. 2003) and rate (Grabber et al. 2009) of forage degradation in grasses. Genetic variation for HCA's has been observed in perennial ryegrass (Lam et al. 2003) but this variation has yet to be exploited in breeding. To support processing large sample numbers in breeding applications, modification of existing analysis protocols for HCA's (Lam et al. 2003; Waldron et al. 1996) was necessary.

HCA's in the cell wall are connected by esterified or etherified linkages, for which separate extractions are required (Sun et al. 2001; Lam et al. 2003) before analysis by high pressure liquid chromatography (HPLC) coupled to ultraviolet (UV) or mass spectrometric (MS) 
detection. Extraction of esterified HCA's is achieved by cleavage with a mild base (Beveridge et al. 2000), but etherified HCA's require stronger conditions for release, remaining intact unless subjected to extreme temperatures under strongly basic conditions (Lam et al. 1994). Consequently, the traditional extraction method for quantification of etherified HCA's requires specialised chambers to contain the extreme pressures generated, and is a costly, labour-intensive process.

A standardised esterified HCA method that has fewer extraction steps was established. Concurrently, an alternative analysis for etherified HCA's, simpler and more cost-effective, was also developed. During extraction of esterified HCA's, compounds were released and subsequently precipitated. These precipitates were solubilised and analysed by liquid chromatography mass spectrometry. Due to the nature of the extraction (saponification) under which they are released, these compounds are most likely higher molecular weight cell wall oligomers (provisionally, CWO's A-H). The CWO's are not the etherified HCA's described in previous studies (Sun et al. 2001) but are likely to be larger moieties comprising linkage groups (including etherified HCA's) between lignin and polysaccharides. Analysis of these compounds has not been reported previously. The new analytical procedures described as follows were applied in concurrent experiments.

\section{Dry matter degradation kinetics in relation to cell wall composition}

In sacco rumen incubation techniques (Ørskov \& McDonald 1979) may be used to estimate parameters

Table 1 In sacco dry matter degradation rate, $\mathrm{k}$, of 24 perennial ryegrass populations. Elite $=$ cultivar or breeding pool; exotic = unimproved, natural population. Endophyte status indeterminate except where indicated.

\begin{tabular}{|c|c|c|c|}
\hline Population ID & Country of origin & Type & Degradation rate $k$ \\
\hline Tunisia-11" & Tunisia & exotic & 0.096 \\
\hline France-14" & France & exotic & 0.097 \\
\hline Suckling collection" & $N Z$ & elite & 0.098 \\
\hline 'Samson' (nil endophyte)" & $N Z$ & elite & 0.101 \\
\hline 'Revolution' AR1 & $N Z$ & elite & 0.102 \\
\hline France-7 & France & exotic & 0.103 \\
\hline 'Aries HD' AR1 & NZ & elite & 0.104 \\
\hline Sp-6 & Spain & exotic & 0.106 \\
\hline Portugal-11 & Portugal & exotic & 0.107 \\
\hline Sweden & Sweden & exotic & 0.108 \\
\hline ‘Samson’ AR1 & $\mathrm{NZ}$ & elite & 0.109 \\
\hline Coronet $^{\natural \S}$ & $N Z$ & elite & 0.111 \\
\hline Italy-10" & Italy & exotic & 0.112 \\
\hline Tivoli & Italy & elite & 0.112 \\
\hline Pamir & Italy & elite & 0.116 \\
\hline Tunisia-5ף & Tunisia & exotic & 0.118 \\
\hline Turkey-9" & Turkey & exotic & 0.119 \\
\hline Fra-12 & France & exotic & 0.119 \\
\hline Turk-2 & Turkey & exotic & 0.120 \\
\hline Spain-1 & Spain & exotic & 0.120 \\
\hline Tunisia-10" & Tunisia & exotic & 0.122 \\
\hline Tunisia-9" & Tunisia & exotic & 0.127 \\
\hline Iran-3" & Iran & exotic & 0.133 \\
\hline Turkey-12" & Turkey & exotic & 0.135 \\
\hline mean & & & 0.113 \\
\hline LSD $_{0.05}$ & & & 0.020 \\
\hline
\end{tabular}

"Evaluated for fibre composition (Table 2); §Turf cultivar 
Table 2 Pearson linear correlations between relative concentrations of cell wall components of 12 perennial ryegrass populations and in sacco DM degradation rate, $k$. Population data are means $(n=4)$. CWO = cell wall oligomer; $\operatorname{DiFA}=$ diferulic acid; DiPA = diphenolic acid.

\begin{tabular}{lll}
\hline Cell wall component & Correlation $\left(\mathrm{r}^{2}\right)$ to $k$ & $\mathrm{P}$ \\
\hline Total DiFA & -0.37 & $<0.05$ \\
5,5'-DiFA & -0.33 & $<0.05$ \\
8,8'-DiFA aryltetralin & -0.47 & $<0.05$ \\
8-O-4'-DiFA & -0.40 & $<0.05$ \\
DiPA A & -0.58 & $<0.01$ \\
DiPA B & -0.63 & $<0.01$ \\
CWO F & 0.45 & $<0.05$ \\
CWO H & 0.45 & $<0.05$ \\
\hline
\end{tabular}

Figure 1 Examples of relationships between relative concentrations of individual cell wall components and in sacco DM degradation rate $k$ amongst 12 perennial ryegrass populations ( $c f$ Table 2). Shown are relationships between $k$ and (a) 8,8'-DiFA aryltetralin, (b) diphenolic acid B, (c) cell wall oligomer H. All data are means $(n=4)$. Error bars are $\mathrm{LSD}_{0.05}$.

(a)

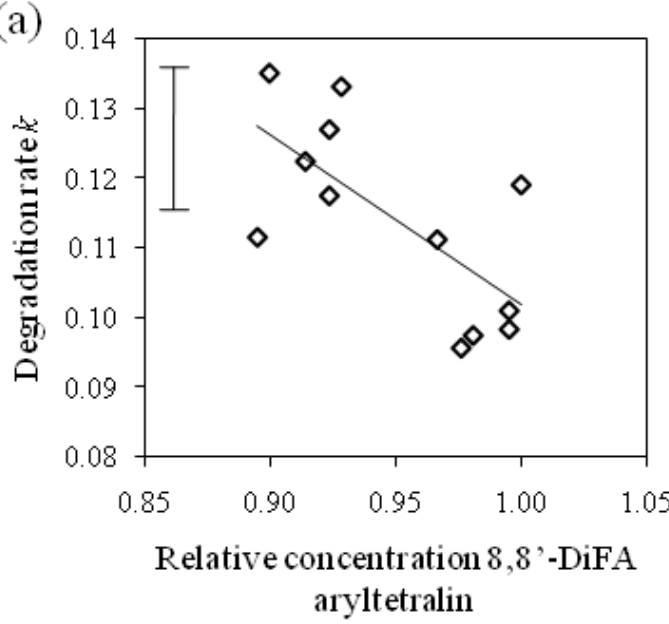

(c)

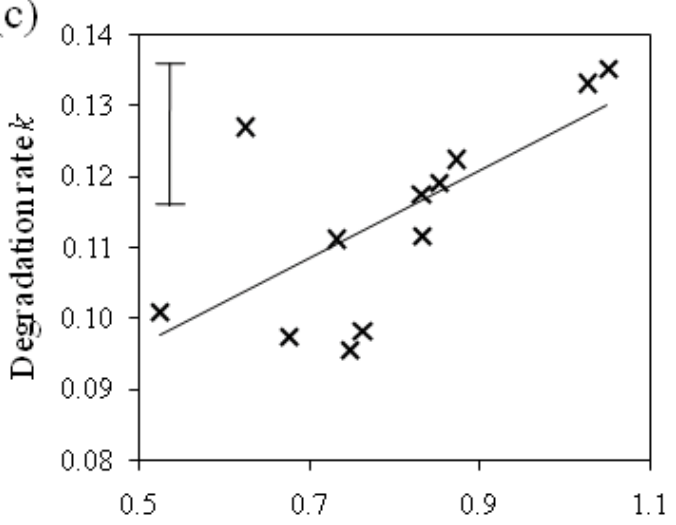

(b)

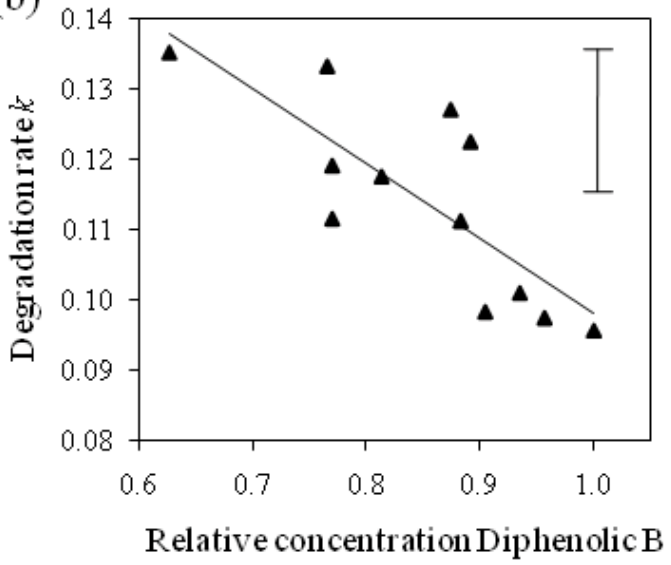

Relative concentration Oligomer $\mathrm{H}$ 
that describe forage degradation in the rumen, including degradation rate $k$, the fractional disappearance rate of the insoluble but degradable fraction. Measurement of in sacco degradation kinetics is not a viable option for screening individual plants in a breeding programme, so our primary objective was to identify cell wall chemical components correlated with degradation rate that might provide an indirect proxy for selection.

Limited variation for fibre composition can exist amongst elite ryegrass populations (Taweel et al. 2005), so 24 perennial ryegrass populations of more diverse origin (Table 1) were established in a replicated $(n=4)$ randomised complete block design row trial, in Palmerston North in November 2008. Herbage was harvested $4 \mathrm{~cm}$ above ground (third cut post-sowing, 5 week regrowth) in March 2009, and was frozen and sub-sampled for chemical analyses using near-infrared reflectance spectroscopy (NIRS; FeedTECH, Palmerston North) and new analytical procedures for HCA and CWO fibre components. Known esterified HCA's were identified by comparison to reference compounds, or based on UV profiles or MS fragmentation patterns. Six new peaks observed in HPLC-UV chromatograms during analysis, corresponding to unidentified diphenolic acids (DiPA's A to $\mathrm{F}$ ), were also quantified. The remaining harvested herbage was used to estimate in sacco degradation kinetics, based on the time course of dry matter (DM) disappearance from minced grass fermented in nylon bags in a cow rumen (Sun et al. 2010). Degradation kinetic parameters, including $k$, were estimated according to López et al. (1999) from the time course of disappearance. The parameter $k$ is the fractional disappearance rate of the insoluble but degradable fraction of DM; a low $k$ value indicates a low rate of degradation.

There was significant $(\mathrm{P}<0.05)$ variation for $k$ amongst 24 populations (Table 1), ranging from 0.096 to $0.135 / \mathrm{h}$, values consistent with earlier observations (Chaves et al. 2006; Sun et al. 2010). Although most of the populations did not differ significantly in $k$, the top three degraded significantly faster than the three slowest ones $(\mathrm{P}<0.05)$. Five New Zealand forage cultivars (Table 1) were at the low (slower rate of degradation) end of the observed range $(0.101-0.109 / \mathrm{h})$ of $k$.

Associations between cell wall chemistry and $k$ were investigated by analysing a subset of 12 populations representing a range of $k$ (Table 2). No significant correlation was observed between $k$ and either acid detergent lignin (ADL) or neutral detergent fibre (NDF) measured by NIRS. In contrast, a number of fibre chemical components, including individual DiFA's, DiPA's and CWO's, showed significant correlation with $k$ (Table 2; Fig. 1).

Fibre content (measured as NDF) has been used by breeders as a selection criterion to improve intake potential of forages. Degradability of the fibre is also an important factor in voluntary intake (Jung \& Allen 1995) but genetic reduction of NDF per se does not affect fibre degradability (Casler 2000) and this was supported by the lack of relationship between NDF and degradation of the potentially digestible DM fraction in the current study. Selection for reduced NDF in perennial ryegrass may also be limited by low levels of variation (Smit et al. 2005) with the potential to negatively affect forage yield (Suprenant et al. 1988; Casler \& Diaby 2008).

The current results indicate that selection of plants for specific DiFA, DiPA and CWO compounds offers a potential means to enhance DM degradation rate and, accordingly, intake potential in perennial ryegrass through plant breeding. Further work to validate these relationships is in progress.

\section{Evaluation of variation for fibre composition in perennial ryegrass}

A range of perennial ryegrass germplasm, including New Zealand cultivars and unadapted populations of diverse origin, was characterised for variation in fibre chemical components that may impact forage degradability, including HCA's and lignin concentration (Grabber et al. 2009). Unadapted plant germplasm

Table 3 Estimated means, ranges and genotypic variance $\left(\sigma_{g}^{2}\right)$ components with associated standard errors ( \pm SE) for concentrations of selected fibre components of 70 perennial ryegrass populations measured in March 2008 and 2009. Means based on two herbage harvests except where indicated. NDF and ADL are expressed as g/kg DM and DiFA's as relative concentrations.

\begin{tabular}{lclccc}
\hline Component & Mean & Range & Range amongst NZ cultivars ${ }^{\S}$ & LSD $_{0.05}$ & $\sigma^{2}{ }_{9} \pm$ SE \\
\hline NDF & 417 & $401-430$ & $414-428$ & 18 & $24.9 \pm 11.16$ \\
ADL & 31.5 & $29.6-33.6$ & $29.6-30.9$ & 2.2 & $0.19 \pm 0.082$ \\
5,5'-DiFA & 51.7 & $43.6-60.1$ & $52.8-60.1$ & 6.4 & $90.5 \pm 31.20$ \\
8,8'-DiFA arylt- & 263 & $206-305$ & $278-305$ & 66 & $1101 \pm 403$ \\
etralin" & & & $347-405$ & 85 & $1719 \pm 660$ \\
8-O-4'-DiFA" & 335 & $265-405$ & & & \\
\hline
\end{tabular}

"March 2009 only; \$Five populations 
may harbour genetic variability not represented in elite breeding pools (Barrière et al. 2006). This research will facilitate benchmarking of New Zealand cultivars in the range of compositional diversity and identify natural variants with the potential to promote genetic gain for fibre composition in breeding.

An outdoors pot trial in a row-column design was established at Palmerston North in September 2007 with 310 plants ( $\mathrm{n}=2$ replicates) from 70 populations, including five New Zealand cultivars, and was cut (ca. $6 \mathrm{~cm}$ ) every 6-8 weeks. Leaf blades (4 weeks regrowth) sampled in March 2008 and 2009 were evaluated for esterified HCA's and by NIRS. Two DiFA's correlated with DM degradation rate (previous section), 8, ' '-DiFA aryltetralin and 8-O-4'-DiFA, were analysed in 2009 only. However, 5,5'-DiFA correlated well with these and other DiFA's in $2009\left(\mathrm{r}^{2}, 0.5-0.8, \mathrm{P}<0.001\right)$ and was considered as a marker for these compounds in the 2008 dataset.

There was significant $(\mathrm{P}<0.05)$ genotypic variation amongst the 70 perennial ryegrass populations for concentrations of selected fibre components (Table 3), indicating the potential genetic variation for fibre traits available for application in perennial ryegrass cultivar development. A narrow range for fibre concentration (NDF) was observed, but there was more extensive variation for fibre components, including esterified DiFA's and ADL (Table 3). New Zealand cultivars were characterised by lower than average ADL and higher levels of DiFA's.

Populations with low levels of DiFA's included several Tunisian populations (five within the 15 lowestranked populations for 5,5'-DiFA). These unadapted populations may be useful sources of genetic variation for reducing DiFA levels in elite breeding populations. Potential for selection within elite cultivars was also indicated by within-population genotypic variation for ADL and DiFA's (data not presented).

These findings will be augmented by further seasonal evaluation and measurement of DiPA's and CWO's shown (see previous section) to correlate with $k$. Nevertheless, current results indicate potential for genetic gain to be made for fibre composition, and consequently forage degradability in perennial ryegrass. Divergent selection within elite breeding pools and crossing of superior unadapted populations to elite plants, to generate plant material for breeding and proof-of-concept animal feeding trials was commenced in 2008. Variation for fibre composition may be influenced by morphogenetic or structural variation; therefore overall agronomic performance will be monitored in conjunction with fibre compositional selection.

\section{GM approaches to improving fibre traits In planta down-regulation of lignin genes}

Techniques which enable the introduction of genetic constructs into perennial ryegrass are well established (Wang et al. 2001) and are a valuable resource for the production of plants with modified traits as the result of altered gene expression profiles. Plants produced by these means may be used either as a tool to increase knowledge of gene regulation and their function, or as a direct means to accelerate trait development in traditional breeding programmes.

Two lignin biosynthetic genes, cinnamyl alcohol dehydrogenase (CAD) and caffeic O-methyl transferase (COMT), form key targets for genetic modification in plants with the expression and regulation of these genes well characterised in several grass species (Aldwin \& Lewis 2002). A series of naturally occurring loss-offunction mutations known as brown mid rib $(b m r)$ have been useful in the characterisation of these genes (for review see Sattler et al. 2010). In maize, CAD activity in the bmr-1 mutant is reduced to as little as $14 \%$ of the normal level dependent on tissue type, genotype and developmental stage (Halpin et al. 1998) while the $b m r-3$ mutation limits COMT expression to $10 \%$ of the wild-type (Grand et al. 1985). Plants affected by these mutations contain significantly reduced lignin content and increased cell wall digestibility (Barriere $e t$ al. 2006).

To date GM approaches for reduced lignin content or altered lignin composition for improved cell wall digestibility have been demonstrated in grasses. Downregulation of CAD and COMT in tall fescue resulted in $14 \%$ and $28 \%$ reductions of total lignin, respectively. In turn, the in vitro dry matter digestibility of these plants was increased by $7.2 \%$ for CAD and $10.8 \%$ for COMT (Chen et al. 2003; 2004). These plants were phenotypically normal and analysis indicated no significant changes in the cellulose, hemicellulose, neutral sugar content, P-coumaric acid or ferulic acid levels. Similarly, $15-30 \%$ reductions of COMT activity have been achieved in maize which subsequently improved cell wall digestion (Piquemal et al. 2002; He et al. 2003).

In ryegrass we have developed a population of transformed plants containing genetic constructs targeted to CAD and COMT. Five down-regulation constructs were designed from previously published sequences of ryegrass genes (McAlister et al. 1998; 2001). Whole plasmid DNA containing the genetic construct was transformed into embryogenic cell cultures using micro-projectile bombardment for the generation of GM plants. About 129 independently transformed lines containing either gene have been recovered. 
Molecular techniques have quantified temporal expression of the endogenous CAD and COMT from vegetative through to floral developmental phases. Minimal expression was observed during vegetative growth but steadily increased through the floral transition peaking after emergence of the inflorescence. This has allowed us to precisely match gene expression levels at each plant growth stage. Using these data we are beginning to identify transformed lines with reduced COMT expression, compared to nontransformed control plants. Subsequently, the chemical and biological tools described above will be used to determine the influence of the transgene upon fibre composition and DM degradation kinetics. Lines with improved digestion characteristics will be available for introduction into molecular breeding programs.

\section{Surrogate delivery of fibre-degrading enzymes by endophyte}

Cool season grasses, including perennial ryegrass, are frequently infected with fungal endophytes of the genera Epichloë and Neotyphodium. Production of plantprotective alkaloids by endophytes in planta, means this interaction has been extensively characterised and commercially exploited using selected endophyte strains (Tapper \& Latch 1999). A popular GM strategy to improve fibre degradation in plants is to express enzymes in planta that break down cell wall structures (Nsereko et al. 2008; Buanafina et al. 2010). We are investigating an analogous avenue for improvement of plant fibre degradation in the rumen that uses endophyte as a delivery vector for such enzymes.

The rationale for this approach is based on many fungal species having been shown to possess highly efficient enzymatic systems for fibre degradation (Sanchez 2009), making endophytes ideal candidates for delivering fungal fibrolytic enzymes to the rumen. Another advantage relates to eliminating the commonly perceived risk of pollen dispersal associated with GM plants, as endophytes are not transmitted by pollen (Scott 2001).

Genetic constructs, designed to over-express genes for three fibre-degrading enzymes sourced from rumen fungi, were synthesised and used to transform Epichloë festucae strain, FL1. Genes used in the constructs included: cellulase D (CelD), which randomly cuts cellulose chains (Lynd et al. 2002), xylanase A (XynA) which cleaves specific linkages in hemicellulose chains (Gilbert et al. 1992), and ferulic acid esterase A (FaeA) which cleaves the ester bond between ferulic acid and arabinose (de Vries et al. 1997). Both CelD and XynA were derived from the rumen anaerobic fungus Neocallimastix patriciarum, while FaeA originates from Aspergillus niger. Genes were constitutively expressed and signal sequences incorporated to ensure localisation of the expressed enzymes in the endoplasmic reticulum, to avoid cell wall disruption by enzyme export into the apoplast before the plant is ingested. Over 50 transformed lines from each construct were rescued and transformants identified for further analysis. Inoculation of these lines into ryegrass will provide plant material for evaluation of DM digestion in vitro and in sacco to determine the effectiveness of this novel GM strategy.

\section{Concluding remarks}

Conventional breeding and GM strategies are being exploited to improve degradability of perennial ryegrass in the rumen. New analytical tools for fibre components, determination of relationships between fibre components and forage degradability and identification of genetic variation for composition, may facilitate improvement of forage degradation in ryegrass breeding. GM technologies for down-regulating lignin biosynthesis in plants or over-expressing fibre-degrading genes in endophyte, show promise as a means of developing materials with improved digestion characteristics for introduction into breeding programs.

\section{ACKNOWLEDGEMENTS}

This work was funded by New Zealand dairy farmers through DairyNZ, and by the Pastoral 21 Consortium and the New Zealand Foundation for Research, Science and Technology (contract C10X0815). We thank Jana Schmidt, Michele Thornton, Michelle Turner, Michael Hickey, Heike Schwendel and Guiguo Zhang for technical assistance, and Drs John Koolaard and Dongwen Luo for statistical advice and analyses.

\section{REFERENCES}

Aldwin, A.M.; Lewis, N.G. 2002. Trends in lignin modification: a comprehensive analysis of the effects of genetic manipulation/mutations on lignification and vascular integrity. Phytochemistry 61: 221-294.

Allen, M.S. 1996. Physical constraints on voluntary intake of forages by ruminants. Journal of Animal Science 74: 3063-3075.

Barrière, Y.; Denoue, D.; Briand, M.; Simon, M.; Jouanin, L.; Durand-Tardif, M. 2006. Genetic variations of cell wall digestibility related traits in floral stems of Arabidopsis thaliana accessions as a basis for the improvement of the feeding value in maize and forage plants. Theoretical and Applied Genetics 113: 163-175.

Beveridge, T.; Loubert, E.; Harrison, J.E. 2000. Simple measurement of phenolic esters in plant cell walls. Food Research International 33: 775-783.

Baumont, R.; Prache, S.; Meuret, M.; Morand-Fehr, P. 2000. How forage characteristics influence behaviour 
and intake in small ruminants: a review. Livestock Production Science 64: 15-28.

Buanafina M.M. de O.; Langdon, T.; Hauck, B.; Dalton, S.; Timms-Taravella, E.; Morris, P. 2010. Targeting expression of a fungal ferulic acid esterase to the apoplast, endoplasmic reticulum or golgi can disrupt feruloylation of the growing cell wall and increase the biodegradability of tall fescue (Festuca arundinacea). Plant Biotechnology Journal 8: 316331.

Casler, M.D. 2000. Breeding forage crops for increased nutritional value. Advances in Agronomy 71: 51-107.

Casler, M.D.; Jung H.-J.G. 1999. Selection and evaluation of smooth bromegrass clones and divergent lignin and etherified ferulic acid concentration. Crop Science 39: 1866-1873.

Casler, M.D.; Diaby, M. 2008. Positive genetic correlation between forage yield and fiber of smooth bromegrass. Crop Science 48: 2153-2158.

Casler, M.D.; Jung, H.G.; Coblentz, W.K. 2008. Clonal selection for lignin and etherified ferulates in three perennial grasses. Crop Science 48: 424-433.

Chaves, A.V.; Waghorn, G.C.; Brookes, I.M.; Woodfield, D.R. 2006. Effect of maturation and initial harvest dates on the nutritive characteristics of ryegrass (Lolium perenne L.). Animal Feed Science and Technology 127: 293-318.

Chen, L.; Auh, C-K.; Dowling, P.; Bell, J.; Chen, F.; Hopkins, A.; Dixon R.A.; Wang, Z-Yu. 2003. Improved forage digestibility of tall fescue (Festuca arundinacea) by transgenic down-regulation of cinnamyl alcohol dehydrogenase. Plant Biotechnology Journal 1: 437-449.

Chen, L.; Auh, C-K.; Dowling, P.; Bell, J.; Lehmann, D.; Wang, Z-Y. 2004. Transgenic down-regulation of caffeic acid $O$-methyltransferase (COMT) led to improved digestibility on tall fescue (Festuca arundinacea). Functional Plant Biology 31: 235-245. de Vries, R.P.; Michelsen, B.; Poulsen, C.H.; Kroon, P.A.; van den Heuvel, R.H.; Faulds, C.B.; Williamson, G.; van den Hombergh, J.P.; Visser J. 1997. The faeA genes from Aspergillus niger and Aspergillus tubingensis encode ferulic acid esterases involved in degradation of complex cell wall polysaccharides. American Society of Microbiology 63: 4638-4644.

Gilbert H.J.; Hazlewood G.P.; Laurie J.I.; Orpin C.G.; Xue G.P. 1992. Homologous catalytic domains in a rumen fungal xylanase: evidence for gene duplication and prokaryotic origin. Molecular Microbiology 6: 2065-2072.

Grabber, J.H.; Ralph, J.; Lapierre, C.; Barrière, Y. 2004. Genetic and molecular basis of grass cell-wall degradability. I. Lignin-cell wall matrix interactions. Plant Biology and Pathology 327: 455-465.
Grabber, J.H.; Mertens, D.R.; Kim, H.; Funk, C.; Lua, F.; Ralph, J. 2009. Cell wall fermentation kinetics are impacted more by lignin content and ferulate cross-linking than by lignin composition. Journal of the Science of Food and Agriculture 89: 122-129.

Grand, C.; Parmentier, A.; Boudet, A.M. 1985. Comparison of lignins and of enzymes involved in ligninficationin normal and midrib ( $b m 3)$ mutation corn seedlings. Physiologie Vegetale 23: 905-911.

Halpin, C.; Holt, K.; Chojecki, J.; Oliver, D.; Chabbert, B.; Monties, B.; Edwards, K.; Barakate, A.; Foxon G. A. 1998. Brown-midrib maize (bm1) - a mutation affecting the cinnamyl alcohol dehydrogenase gene. The Plant Journal 14: 545-553.

Hatfield, R.D.; Ralph, J.; Grabber, J.H. 1999. Cell wall cross-linking by ferulates and diferulates in grasses. Journal of the Science of Food and Agriculture 79: 403-407.

He, X.; Hall, M.B.; Gallo-Meagher, M.; Smith, R.L. 2003. Improvement of forage quality by downregulation of maize o-methyltransferase. Crop Science 43: 2240-2251.

Jung, H.G.; Allen M.S. 1995. Characteristics of plant cell walls affecting intake and digestibility of forages by ruminants. Journal of Animal Science 73: 27742790.

Jung, H.G.; Deetz, D.A. 1993. Cell wall lignification and degradability. pp. 315-346. In: Forage cell wall structure and digestibility. Eds. Jung, H.G.; Buxton, D.R.; Hatfield, R.D; Ralph, J. American Society of Agronomy, Madison, WI.

Kristensen, T.; Søegaard, K.; Kristensen, I.S. 2005. Management of grasslands in intensive dairy livestock farming. Livestock Production Science 96: 61-73.

Lam, T.B.-T.; Iiyama, K.; Stone, B.A. 1994. Determination of etherified hydroxycinnamic acids in cell walls of grasses. Phytochemistry 36: 773-775.

Lam, T.B.-T.; Iiyama, K.; Stone, B.A. 2003. Hot alkalilabile linkages in the walls of the forage grass Phalaris aquatica and Lolium perenne and their relation to in vitro wall digestibility. Phytochemistry 64: 603-607.

López, S.; France, J.; Dhanoa, M.S.; Mould, F.; Dijkstra, J. 1999. Comparison of mathematical models to describe disappearance curves obtained using the polyester bag technique for incubating feeds in the rumen. Journal of Animal Science 77: 1875-1888.

Lynd L.R.; Weimer P.J.; van Zyl W.H.; Pretorius I.S. 2002. Microbial cellulose utilization: fundamentals and biotechnology. Microbiology and Molecular Biology Reviews 66: 506-577.

McAlister, F. M.; Jenkins, C. L. D.; Watson J. M. 1998. Sequence and expression of a stem-abundant caffeic acid $O$-methytransferase cDNA from perennial 
ryegrass (Lolium perenne). Australian Journal of Plant Physiology 25: 225-235.

McAlister, F.M.; Lewis-Henderson, W. R.; Jenkins C.L.D.; Watson J.M. 2001. Isolation and expression of a cinnamyl alcohol dehydrogenase cDNA from perennial ryegrass (Lolium perenne). Australian Journal of Plant Physiology 28: 1085-1094.

Nsereko V.L.; Smiley, B.K.; Rutherford, W.M.; Spielbauer, A.; Forrester, K.J.; Hettinger, G.H.; Harman, E.K.; Harman, B.R. 2008. Influence of inoculating forage with lactic acid bacterial strains that produce ferulate esterase on ensilage and ruminal degradation of fiber. Animal Feed Science and Technology 145: 122-135.

Ørskov, E.R.; McDonald, I. 1979. The estimation of protein degradability in the rumen from incubation measurements weighed according to rate of passage. Journal of Agricultural Science, Cambridge 92: 499503.

Piquemal, J.; Chamayou, S.; Nadaud, I.; Beckert, M.; Barriers, Y.; Mila, I.; Lapierre, C.; Rigqu, J.; Puigdomenech, P.; Jauneau, A.; Digonnet, C.; Boudet, A-M.; Goffner, D.; Pichon, M. 2002. Down regulation of Caffeic Acid O-Methyltransferase in maize revisited using a transgenic approach. Plant Physiology 130: 1675-1685.

Sanchez, C. 2009. Lignocellulosic residues: biodegradation and bioconversion by fungi. Biotechnology Advances 27: 185-194.

Sattler, S.E.; Funnell-Harris, D.L.; Pedersen, J.F. 2010. Brown midrib mutations and their importance to the utilization of maize, sorghum and pearl millet lignocellulosic tissues. Plant Science 178: 229-238.

Scott, B. 2001. Epichloe endophytes: fungal symbionts of grasses. Current Opinion in Microbiology 4: 393398.

Smit, H.J.; Tas, B.M.; Taweel, H.Z.; Tamminga, S.; Elgersma A. 2005. Effects of perennial ryegrass (Lolium perenne L.) cultivars on herbage production, nutritional quality and herbage intake of grazing dairy cows. Grass and Forage Science 60: 297-309.
Sun, R.-C.; Sun, X.-F.; Zhang, S.-H. 2001. Quantitative determination of hydroxycinnamic acids in wheat, rice, rye, and barley straws, maize stems, oil palm frond fiber, and fast-growing poplar wood. Journal of Agricultural and Food Chemistry 49: 5122-5129.

Sun, X.Z.; Waghorn, G.C.; Clark, H. 2010. Cultivar and age of regrowth effects on physical, chemical and in sacco degradation kinetics of vegetative perennial ryegrass (Lolium perenne L.). Animal Feed Science and Technology 155: 172-185.

Surprenant, J.; Barnes, D.K.; Busch, R.H.; Marten, G.C. 1988. Bidirectional selection for neutral detergent fiber and yield in reed canarygrass. Canadian Journal of Plant Science 68: 705-712.

Tapper B.A.; Latch, G.C.M. 1999. Selection against toxin production in endophyte infected perennial ryegrass. Ryegrass endophyte: an essential New Zealand symbiosis. Grassland Research and Practice Series 7: 107-111.

Taweel, H.Z.; Tas, B.M.; Smit, H. J.; Elgersma, A.; Dijkstra, J.; Tamminga, S. 2005. Improving the quality of perennial ryegrass (Lolium perenne L.) for dairy cows by selecting for fast clearing and/ or degradable neutral detergent fiber. Livestock Production Science 96: 239-248.

Waldron, K.W.; Parr, A.J.; Ng, A.; Ralph, J. 1996. Cell wall esterified phenolic dimers: Identification and quantification by reverse phase high performance liquid chromatography and diode array detection. Phytochemical Analysis 7: 305-312.

Wang, Z-Yu.; Hopkins, A.; Mian, R. 2001. Forage and Turf Grass Biotechnology. Critical Reviews in Plant Sciences 20: 573-619. 